\title{
Paleo-modeling of coastal saltwater intrusion during the Holocene: an application to the Netherlands
}

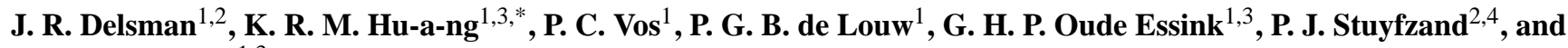 \\ M. F. P. Bierkens ${ }^{1,3}$ \\ ${ }^{1}$ Unit Subsurface and Groundwater Systems, Deltares, P.O. Box 85467, 3508 AL Utrecht, the Netherlands \\ ${ }^{2}$ Critical Zone Hydrology Group, Department of Earth Sciences, VU University Amsterdam, De Boelelaan 1085, \\ 1081 HV Amsterdam, the Netherlands \\ ${ }^{3}$ Department of Physical Geography, Utrecht University, P.O. Box 80.115, 3508 TC Utrecht, the Netherlands \\ ${ }^{4}$ KWR Watercycle Research Institute, P.O. Box 1072, 3430 BB Nieuwegein, the Netherlands \\ *now at: Acacia Water, Jan van Beaumontstraat 1, 2805 RN Gouda, the Netherlands
}

Correspondence to: J. R. Delsman (joost.delsman@deltares.nl)

Received: 24 October 2013 - Published in Hydrol. Earth Syst. Sci. Discuss.: 13 November 2013

Revised: - - Accepted: 7 August 2014 - Published: 2 October 2014

\begin{abstract}
Coastal groundwater reserves often reflect a complex evolution of marine transgressions and regressions, and are only rarely in equilibrium with current boundary conditions. Understanding and managing the present-day distribution and future development of these reserves and their hydrochemical characteristics therefore requires insight into their complex evolution history. In this paper, we construct a paleo-hydrogeological model, together with groundwater age and origin calculations, to simulate, study and evaluate the evolution of groundwater salinity in the coastal area of the Netherlands throughout the last $8.5 \mathrm{kyr}$ of the Holocene. While intended as a conceptual tool, confidence in our model results is warranted by a good correspondence with a hydrochemical characterization of groundwater origin. Throughout the modeled period, coastal groundwater distribution never reached equilibrium with contemporaneous boundary conditions. This result highlights the importance of historically changing boundary conditions in shaping the present-day distribution of groundwater and its chemical composition. As such, it acts as a warning against the common use of a steady-state situation given present-day boundary conditions to initialize groundwater transport modeling in complex coastal aquifers or, more general, against explaining existing groundwater composition patterns from the currently existing flow situation. The importance of historical boundary conditions not only holds true for the effects of the largescale marine transgression around $5 \mathrm{kyr} \mathrm{BC}$ that thoroughly
\end{abstract}

reworked groundwater composition, but also for the more local effects of a temporary gaining river system still recognizable today. Model results further attest to the impact of groundwater density differences on coastal groundwater flow on millennial timescales and highlight their importance in shaping today's groundwater salinity distribution. We found free convection to drive large-scale fingered infiltration of seawater to depths of $200 \mathrm{~m}$ within decades after a marine transgression, displacing the originally present groundwater upwards. Subsequent infiltration of fresh meteoric water was, in contrast, hampered by the existing density gradient. We observed discontinuous aquitards to exert a significant control on infiltration patterns and the resulting evolution of groundwater salinity. Finally, adding to a long-term scientific debate on the origins of groundwater salinity in Dutch coastal aquifers, our modeling results suggest a more significant role of pre-Holocene groundwater in the present-day groundwater salinity distribution in the Netherlands than previously recognized. Though conceptual, comprehensively modeling the Holocene evolution of groundwater salinity, age and origin offered a unique view on the complex processes shaping groundwater in coastal aquifers over millennial timescales. 


\section{Introduction}

While fresh groundwater reserves in coastal areas are a vital resource for millions of people, they are vulnerable to salinization, given both their proximity to the sea and the usually large demands on freshwater by the larger population densities in coastal areas (Barlow and Reichard, 2009; Custodio and Bruggeman, 1987; Ferguson and Gleeson, 2012; Post and Abarca, 2009; Werner et al., 2013). Reported impacts of salinizing coastal aquifers include the salinization of abstraction wells (Custodio, 2002; Stuyfzand, 1996), decrease of agricultural yield (Pitman and Läuchli, 2002), degrading quality of surface waters (De Louw et al., 2010), and adverse effects on vulnerable ecosystems (Mulholland et al., 1997), issues that will only intensify in the future, given the prospects of global change (Kundzewicz et al., 2008; Oude Essink et al., 2010; Ranjan et al., 2006). The above issues have sparked a surge in renewed scientific interest in the "classic" saltwater intrusion process, i.e., the development of a landward-protruding saline groundwater wedge under the influence of groundwater density differences, as reviewed by Werner et al. (2013).

Given their vulnerability, sustainable management of coastal fresh groundwater reserves is of paramount importance. A prerequisite is an accurate description of the presentday distribution of fresh groundwater reserves. That accurate description is, however, difficult to obtain: measurements are sparse, especially at greater depths, while salinity varies within short distances, driven by relatively minor head gradients that vary over time (De Louw et al., 2011). And although recent advances in airborne geophysics (Faneca Sànchez et al., 2012; Gunnink et al., 2012; Siemon et al., 2009; Sulzbacher et al., 2012) are promising, the availability of airborne data is still limited and its reliability decreases with depth. Variable density groundwater modeling may be used to assess coastal freshwater resources and management strategies (e.g., Nocchi and Salleolini, 2013; Oude Essink et al., 2010). However, as a result of the density feedback of solute concentration on groundwater flow, this requires an adequate description of the initial solute concentration: a vicious circle of having to know the salinity distribution to model the salinity distribution. A frequent workaround is the assumption of steady state, obtained by a spin-up period applying current boundary conditions (e.g., Souza and Voss, 1987; Vandenbohede et al., 2011; Vandenbohede and Lebbe, 2002). However, given the usually long timescales involved, coastal groundwater systems are rarely in equilibrium, often still reflecting events occurring thousands or even millions of years ago (e.g., Groen et al., 2000; Post et al., 2003; Stuyfzand, 1993).

Paleo-hydrogeologic modeling, or the transient modeling of the long-term co-evolution of landscape and groundwater flow, may provide a way out of this vicious circle. This involves starting a model run at a reference point in time where the salinity distribution is either more or less known, or is certain not to influence the present-day salinity distribution. Successful use of paleo-hydrogeologic modeling is difficult however, given the long timescales considered, the often limited availability of data on paleo-boundary conditions and the impossibility of validating past time frames (Van Loon et al., 2009), on top of the "normal" difficulties in hydrogeologic (transport) modeling (Konikow, 2010). Paleo-hydrogeologic modeling has been previously applied to study the influence of groundwater during glacial cycles (Bense and Person, 2008; Lemieux and Sudicky, 2009; Person et al., 2012; Piotrowski, 1997), to better explain the observed pattern in groundwater ages using carbon dating (Sanford and Buapeng, 1996), to study the degradation of fen areas in the Netherlands (Van Loon et al., 2009; Schot and Molenaar, 1992), and to relate archeological settlements to historic phreatic groundwater levels (Zwertvaegher et al., 2013). Applications of paleo-hydrogeologic modeling in variable-density flow situations are scarce however, and are limited to the evolution of fresh- and saltwater over the last century (Nienhuis et al., 2013; Oude Essink, 1996) or millennium (Lebbe et al., 2012; Vandevelde et al., 2012), using available historic information.

In this paper, we apply paleo-hydrogeologic modeling to study the processes controlling the Holocene evolution of groundwater salinity in a representative deltaic coastal aquifer: the coastal region of the Netherlands. The studied region (Sect. 2) has a complex paleo-geographic history of marine trans- and regressions, peat accumulation and degradation, and more recently land reclamation, drainage and groundwater abstraction. The groundwater salinity distribution still reflects this complex history (Oude Essink et al., 2010; Post et al., 2003; Stuyfzand, 1993), and both the paleogeographic evolution (Vos et al., 2011) and the distribution of aquifer properties (Weerts et al., 2005) are relatively well known. As such, the region is well suited to a paleohydrogeologic modeling approach. In addition, societal interest in the region's groundwater salinity distribution is spurred by a deterioration of surface water quality through exfiltration of brackish groundwater, adversely affecting agriculture and vulnerable ecosystems (De Louw et al., 2010; Oude Essink et al., 2010; Van Rees Vellinga et al., 1981). While salinity is the prime focus of the present paper, the approach presented is considered relevant for the many other societally relevant groundwater constituents in coastal aquifers, like nutrients (Van Rees Vellinga et al., 1981; Stuyfzand, 1993) or arsenic (Harvey et al., 2006; Michael and Voss, 2009).

\section{Site description}

\subsection{Study area}

We studied an approximately west-to-east-oriented transect, located some $10 \mathrm{~km}$ south of the city of Amsterdam, the Netherlands (Fig. 1). The $65 \mathrm{~km}$ long transect is oriented perpendicular to the coastline and extends from $12 \mathrm{~km}$ offshore 


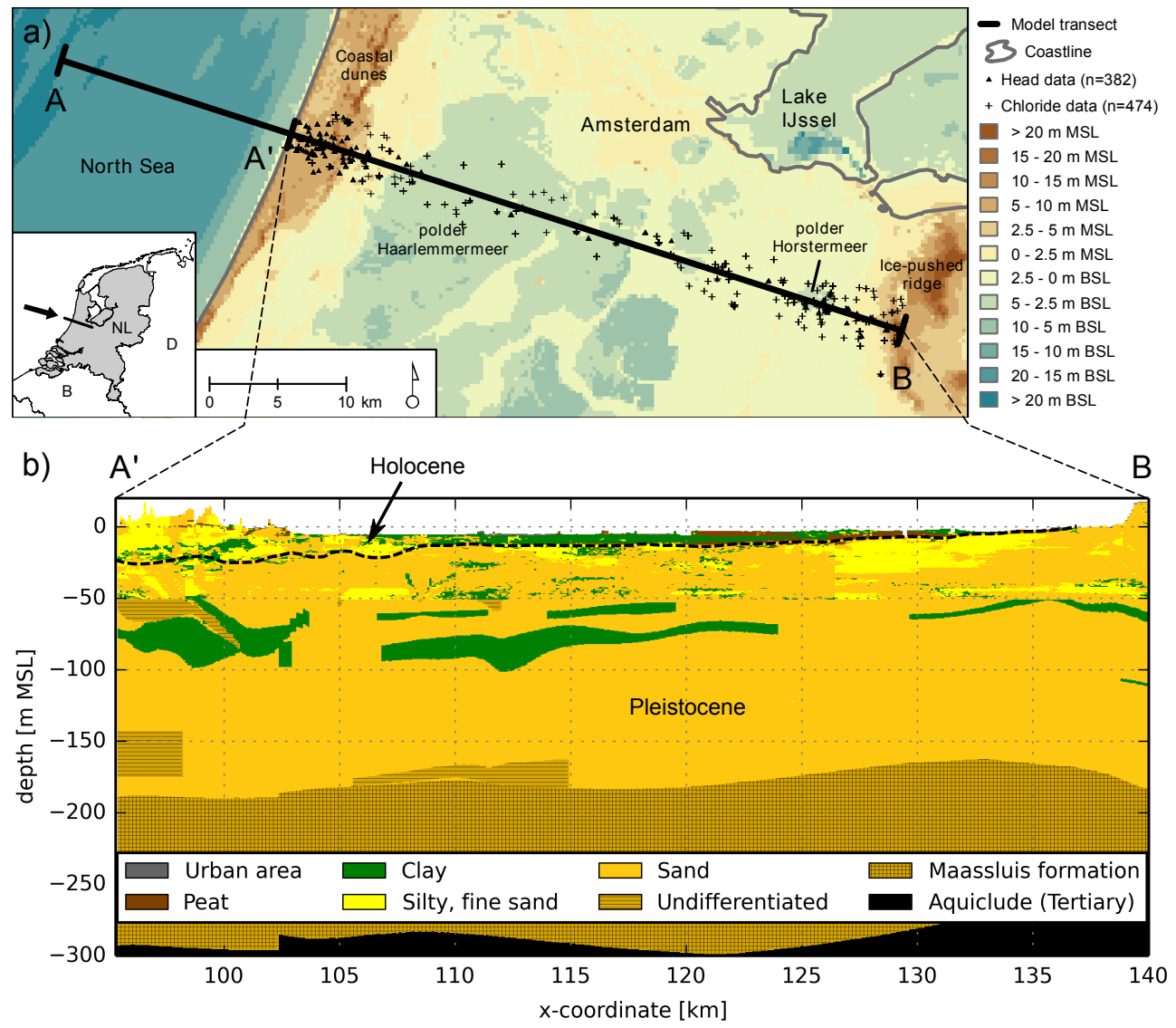

Figure 1. Location of studied transect (A-B), elevation and main topographical features (a), and a lithological cross section along the transect $\left(\mathrm{A}^{\prime}-\mathrm{B}\right)(\mathbf{b})$; dashed line in (b) demarcates Pleistocene and Holocene deposits.

to the midpoint of an ice-pushed ridge, forming a regional groundwater divide. The transect is exemplary for this part of the coastal region of the Netherlands, intersecting coastal sand dunes, reclaimed lakes, managed fen areas and the aforementioned ice-pushed ridge. Elevations along the transect range from $5 \mathrm{~m}$ below mean sea level (b.s.l.) in the deep polder areas, to locally 35 and $30 \mathrm{~m}$ above mean sea level (m.s.l.) for the dune area and ice-pushed ridge, respectively. Present-day climate is categorized as moderate maritime, with temperatures that average $10^{\circ} \mathrm{C}$, an average annual precipitation total of $840 \mathrm{~mm}$, and an average annual Makkink reference evapotranspiration total (Makkink, 1957) of $590 \mathrm{~mm}$ (KNMI, 2010).

The hydrogeology of the area is characterized by $300 \mathrm{~m}$ thick deposits of predominantly Pleistocene marine, glacial and fluvial deposits, forming alternating sandy aquifers and clayey aquitards (Fig. 1b). The Maassluis formation comprises the oldest Pleistocene deposits and includes sandy and clayey sediments of marine origin, limited dated samples indicate remaining connate marine groundwater (Post et al., 2003). An aquiclude of Tertiary clays is present below these deposits (Dufour, 2000). Excluding the coastal dune area, Holocene deposits are generally no more than $10 \mathrm{~m}$ thick, thinning out in an easterly direction. A more elaborate description of these Holocene deposits and their genesis is presented below. Present-day groundwater flow is directed from the elevated dune and ice-pushed ridge areas towards the deep polder areas in the center of the transect. Water management in the central part is aimed at keeping groundwater levels at an optimal level for agriculture, within 1-2 $\mathrm{m}$ below the ground surface, and requires an extensive network of canals, ditches and subsurface drains to drain excess precipitation and exfiltrating groundwater. Flow direction reverses during summer, when freshwater from the river Rhine is redirected to compensate for precipitation deficits and salinity increases.

\subsection{Holocene paleo-geographical development}

An overview of the Holocene paleo-geographical development of the area is presented in Fig. 2. At the end of the Pleistocene, up to about $13000 \mathrm{BC}$, the area was characterized by sandy plains with braided rivers, sloping gently from the ice-pushed ridge towards the contemporaneous coastline. Because of post-glacial sea level rise during the early Holocene, groundwater levels started to rise in the coastal 

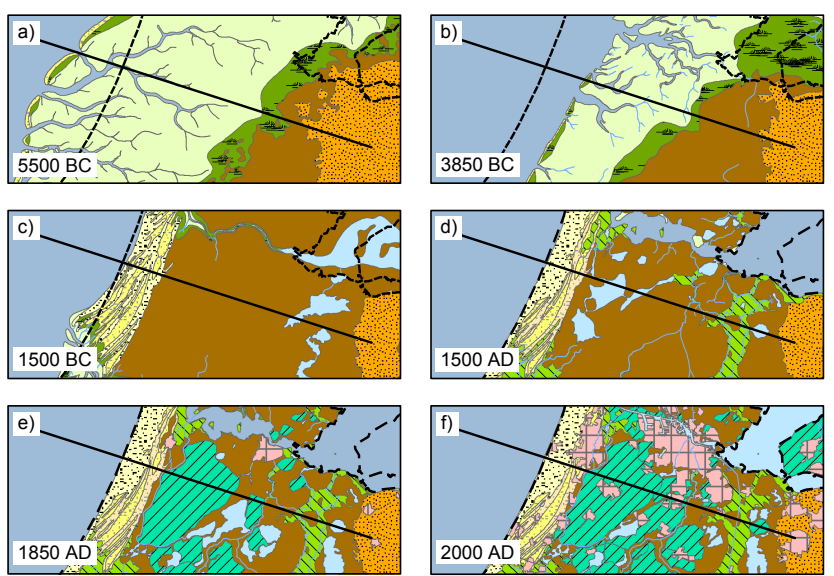

Legend

— Model transect $\square$ Tidal flats

I Present coastline Salt marsh

Water course Dine area (high)

$\square$ Sea Dune area (low)

Beach barrier $\Delta \nabla$ Embanked area

- Peat I/A Reclaimed area

$\square$ Fresh water lake $\square$ Urban area

Fa Floodplain Pleistocene deposits

g)

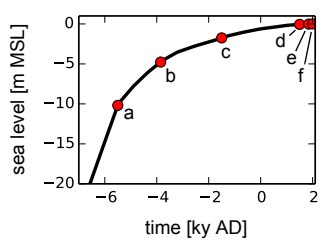

Figure 2. Overview of Holocene paleo-geographical development (a-f) and sea level rise (g, adapted from Van de Plassche, 1982). Red dots and letters in (g) refer to the corresponding paleogeographical map (a-f). For reference, note that the extent of the paleo-geographical maps equals the extent of Fig. 1a.

zone and promoted the widespread formation of peat. The continuing sea level rise resulted around $6500 \mathrm{BC}$ in the submersion of these peat deposits, when an open barrier system with barriers and a tidal basin formed to a maximum extent of about three-quarters of the studied transect (transgression phase). Around $3950 \mathrm{BC}$ the Dutch coast became a closed system, when sediment availability had begun to match the decreased sea level rise rate (regression phase). The coast now changed into a prograding system that extended into the North Sea until 2500 BC. The tidal areas silted up and freshened, stimulating large-scale peat development behind the coastal barriers. Peat development was at a maximum around AD 1000, reaching a maximum thickness of $6 \mathrm{~m}$ (elevation of $2 \mathrm{~m}$ m.s.l.). Subsequently, peat extraction and anthropogenic drainage resulted in rapid peat degradation, a lowering of the ground surface and the eventual formation of several freshwater lakes. Increased sand availability in the coastal zone around AD 900 led to the formation of an extended and higher coastal dune system (Jelgersma et al., 1970). Anthropogenic influence grew in importance from AD 1500 onwards, through land cultivation, improved agricultural drainage, river embankment and urban development. Large-scale land reclamation projects were carried out on most freshwater lakes in the 19th century, resulting in the deep polders of Haarlemmermeer (AD 1852) and Horstermeer (AD 1888). Groundwater abstraction started in the coastal dunes and the ice-pushed ridge in the mid-1800s. Subsequent salinization problems prompted the abandon- ment of most abstraction wells in the coastal dunes in favor of the current Rhine water infiltration scheme in use since 1957, whereby water is infiltrated in infiltration ponds and extracted using recovery canals and horizontal drains.

\subsection{Hydrochemical facies analysis (HYFA)}

In the 1980s, about 20 piezometer nests in the western part of the studied transect, each with four to fifteen $1 \mathrm{~m}$ long monitor well screens, were sampled and analyzed on main constituents, trace elements and environmental tracers (locations and depths in Fig. 6a). Stuyfzand (1993, 1999) used the resulting data set (with many more data from monitor wells along the Dutch coast) to depict the spatial distribution of groundwater bodies with a specific origin (hydrosomes), and their hydrochemical facies (distinct hydrochemical zones within each hydrosome). Environmental tracers $(\mathrm{Cl} / \mathrm{Br}$ ratio, ${ }^{18} \mathrm{O},{ }^{3} \mathrm{H},{ }^{14} \mathrm{C}, \mathrm{SO}_{4}$ and $\mathrm{HCO}_{3}$ ) were used to discern the following hydrosomes, in order of increasing salinity: (i) fresh dune groundwater (rainwater infiltrated in coastal dunes) (in Fig. 6d), (ii) fresh, artificially recharged Rhine River water, (iii) slightly brackish polder water (a mix of rainwater, Rhine River water and exfiltrated Holocene transgression water), which after mixing infiltrated via canals and ditches on a higher topographical level than the deep polders from which the mix originated (P), (iv) two types of brackish groundwater, which infiltrated during the Holocene transgression (LC/Lm), (v) brackish to saline paleo-groundwater upconing from deep marine Tertiary aquitards (M), and (vi) intruding North Sea water (S) (Fig. 6a). Within each hydrosome a variety of hydrochemical facies was discerned by a combination of four aspects: (a) the redox level, as deduced from the concentrations of $\mathrm{O}_{2}, \mathrm{NO}_{3}, \mathrm{SO}_{4}, \mathrm{Fe}, \mathrm{Mn}$ and $\mathrm{CH}_{4}$; (b) the calcite saturation index; (c) a pollution index (POLIN) based on six equally weighted quality aspects; and (d) the Base EXchange index (BEX), defined as the sum of the cations $\mathrm{Na}, \mathrm{K}$, and $\mathrm{Mg}$ (in meq $\mathrm{L}^{-1}$ ), corrected for a contribution of sea salt.

\section{Paleo-hydrogeological modeling}

To model the evolution of groundwater salinity throughout the Holocene, we used the variable density groundwater modeling software SEAWAT (Langevin and Guo, 2006) to set up a 2-D model for the described transect (A-B in Fig. 1a, conceptual outline in Fig. 3). We assumed a Dirichlet boundary condition (sea level) on the western side, and no-flow boundaries (groundwater divide and geohydrological base, taken as the top of Tertiary clays (below the Maassluis formation, Fig. 1b; Dufour, 2000)) on the eastern and bottom side of the transect, respectively. The assumption of no-flow on the eastern side is motivated by the elevated position of the ice-pushed ridge in its surroundings during the entire modeled period and is supported by model results of the national groundwater model of the Netherlands (De Lange et al., 2014). The model domain was divided into six hundred 


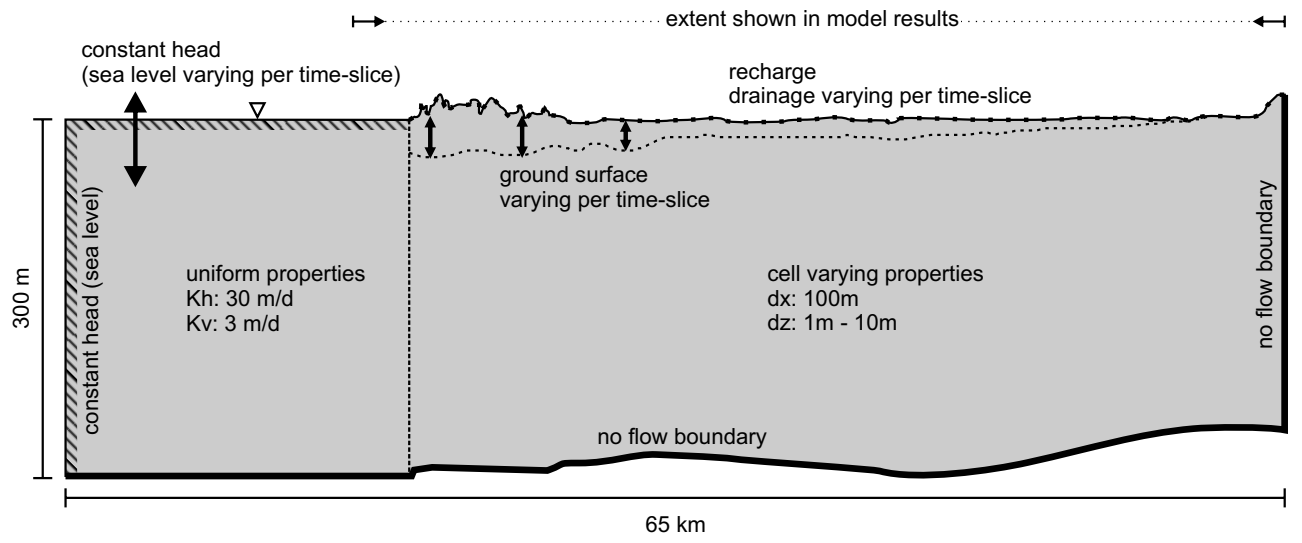

Figure 3. Conceptual model representation.

fifty-one, $100 \mathrm{~m}$ wide model cells in the horizontal, and 102 layers in the vertical, whose thicknesses increase with depth (thickness $1 \mathrm{~m}$ in upper $60 \mathrm{~m}$, increasing to $10 \mathrm{~m}$ at maximum depth) in the vertical. Cell-specific geohydrological properties were taken from national geohydrological databases REGIS (Vernes and Van Doorn, 2005) and GEOTOP (Van der Meulen et al., 2013; Stafleu et al., 2011) (both available from http://www.dinoloket.nl). GEOTOP provides detailed $(100 \times 100 \times 0.5 \mathrm{~m})$ estimates of lithology to a depth of $50 \mathrm{~m}$, we applied REGIS-derived formation-specific hydraulic properties for the deeper subsurface. We assumed a homogeneous aquifer seaward of the present coastline, given the limited availability of geohydrological information. Information on present-day water management was obtained from the Netherlands Hydrological Instrument model (De Lange et al., 2014, available from http://www.nhi.nu).

We used chloride to represent salinity, as chloride is the dominant anion in Dutch coastal groundwater and density is linearly related to it within naturally occurring concentrations. To better understand the evolution of groundwater salinity, we included several fictitious inert tracers, representing the various inputs to the groundwater system, as additional mobile species in the simulation. These tracers were given a concentration of one when they entered the model domain, or were present during model start. We refer to these fictitious tracers as origin tracers in the remainder of this paper. Furthermore, we modeled direct groundwater age (Goode, 1996) by including an additional specie with a negative zero-th order decay term (Zheng, 2009). This specie is zero when entering the model domain, then gains one for every year spent inside the model. An overview of the different origin tracers and their relation to hydrosomes (Sect. 2.3) is presented in Table 1. Longitudinal dispersivity was set to $1 \mathrm{~m}$, the lower bound found for similar settings in experimental work reviewed by Gelhar et al. (1992), and similar to values used in comparable settings (Lebbe, 1999; Oude Essink et al., 2010). Horizontal and vertical transversal dispersivities were assumed 0.1 and $0.01 \mathrm{~m}$, respectively (Zheng and
Wang, 1999), and we assigned a uniform molecular diffusion coefficient of $10^{-9} \mathrm{~m}^{2} \mathrm{~s}^{-1}$. We did not attempt to calibrate our model, recognizing that calibration would only be possible for the most recent periods, and a rigorous sensitivity analysis was impossible given the long calculation times. We regard our model therefore primarily as a conceptual tool. Still, we assessed the validity of the model by comparing model results to measured heads and chloride measurements, tritium-derived groundwater ages and a hydrochemical interpretation of groundwater origin (HYFA, see Sect. 2.3). Available radiocarbon measurements were proven impossible to use for accurate dating in this area, due to the large contribution of heterogeneously aged sedimentary carbon sources to inorganic carbon dissolved in groundwater (Post, 2004).

The geographical changes throughout the Holocene were implemented using 10 successive time slices, with each time slice representing a distinct period in the paleo-geographical evolution (Fig. 2, Table 2). Model start was set at $6500 \mathrm{BC}$, marking the start of marine influence in the area. Conditions during a time slice were assumed constant, with the exception of the rapidly rising sea level (implemented using 10 stress periods) during the first 2 time slices (transgression phase). The model state (head and concentration) at the end of each time slice was used as the starting state for the subsequent time slice; model cells not present in a previous time slice were given the state of the previously uppermost model cell per column. Specific to each time slice were its sea level, surface elevation, near-surface geohydrological properties, drainage structure and groundwater abstractions, which were reconstructed based on the depositional history reflected in the near-surface geological record and various literature sources (Table 3). In addition to reconstructed largerscale drainage structures such as e.g. the river Vecht, we applied infinite drainage at the model surface to represent small streams and creeks. As little erosion has taken place since the start of modeling, and compaction of clay was not considered significant, the near-surface geological record provided a good approximation of the historical landscape. An 
Table 1. Description of modeled origin tracers and relation to hydrosomes.

\begin{tabular}{|c|c|c|}
\hline Tracer & Description & Related hydrosome \\
\hline Maassluis & $\begin{array}{l}\text { Water present in the Maassluis formation (Weerts et al., 2005; see } \\
\text { Fig. 1b) at start of modeling. Note that this tracer is applied irrespec- } \\
\text { tive of the pre-model history of water in this formation, and should } \\
\text { not be confused with connate Maassluis water, enclosed at deposition } \\
\text { of this formation } 2.5 \text { My ago. }\end{array}$ & Maassluis (M) \\
\hline Transgression & $\begin{array}{l}\text { Seawater infiltrating from the surface east of } x \text { coordinate } 95 \mathrm{~km} \\
\text { during transgression phase, i.e., before } 3300 \mathrm{BC}\end{array}$ & $\begin{array}{l}\text { Holocene transgression - coastal type } \\
\text { (LC) }\end{array}$ \\
\hline Sea & Seawater, excluding infiltrating transgression water & Actual North Sea (S) \\
\hline Recharge & Infiltrating meteoric recharge, excluding recharge marshlands & $\begin{array}{l}\text { Dune (D) west of } x \text { coordinate } 105 \mathrm{~km} \text {, } \\
\text { polder (P) east of } 105 \mathrm{~km} \text { (note that the } \\
\text { HYFA analysis does not include the area } \\
\text { east of } x \text { coordinate } 110 \mathrm{~km} \text { ) }\end{array}$ \\
\hline $\begin{array}{l}\text { Recharge } \\
\text { marshlands }\end{array}$ & $\begin{array}{l}\text { Infiltrating meteoric recharge in marshlands between the coastal dunes } \\
\text { and ice-pushed ridge, between } 3300 \mathrm{BC} \text { and } \mathrm{AD} 1500\end{array}$ & $\begin{array}{l}\text { Holocene transgression - ancient marsh } \\
\text { type }(\mathrm{Lm} 1) \text {, and Holocene transgression } \\
\text { - young marsh type }(\mathrm{Lm} 2) \text {. The two are } \\
\text { differentiated based on the } 4 \mathrm{kyr} \text { age con- } \\
\text { tour obtained by direct age calculations } \\
\text { (Goode, 1996) and mixing with transgres- } \\
\text { sion origin. }\end{array}$ \\
\hline Surface water & Infiltrating surface water & Polder (P) \\
\hline Initial & $\begin{array}{l}\text { Groundwater present at model start, excluding Maassluis, sea- and } \\
\text { transgression water }\end{array}$ & - \\
\hline
\end{tabular}

Table 2. Description of model time slices.

\begin{tabular}{|c|c|}
\hline Time slice & Description \\
\hline $6500 \mathrm{BC}-4500 \mathrm{BC}$ & $\begin{array}{l}\text { Sea level rise, linearly from } 22 \text { to } 8 \text { m b.s.l. ( } 10 \text { stress periods). Maximum transgression extent reached. } \\
\text { Tidal area develops over Pleistocene surface, "basal" peat deposits left mostly intact. Surface drainage. }\end{array}$ \\
\hline $4500 \mathrm{BC}-3300 \mathrm{BC}$ & $\begin{array}{l}\text { Sea level rise, linearly from } 8 \text { to } 5 \mathrm{~m} \text { b.s.l. (10 stress periods). Open system with strong marine influence. } \\
\text { Deposition of marine clay and sand. Peat extent expands. }\end{array}$ \\
\hline $3300 \mathrm{BC}-2100 \mathrm{BC}$ & $\begin{array}{l}\text { Sea level at } 3.5 \mathrm{~m} \text { b.s.l. Closed system, freshening of hinterland. Peat development behind barriers, } \\
\text { peat elevation } 3 \mathrm{~m} \text { b.s.l. }\end{array}$ \\
\hline $2100 \mathrm{BC}-700 \mathrm{BC}$ & Sea level at $2 \mathrm{~m}$ b.s.l. Peat development accelerates, peat domes rise to $1 \mathrm{~m}$ m.s.l. \\
\hline $700 \mathrm{BC}-\mathrm{AD} 500$ & Sea level at $1 \mathrm{~m}$ b.s.l. Peat elevation $1.5 \mathrm{~m}$ m.s.l. River Vecht system develops ( $0.7 \mathrm{~m}$ b.s.l.). \\
\hline AD 500-AD 1500 & Sea level at $1 \mathrm{~m}$ b.s.l. Maximal peat elevation: $2 \mathrm{~m}$ m.s.l. "young dunes" develop, coastal dunes rise to $12 \mathrm{~m}$ m.s.l. \\
\hline AD 1500-AD 1850 & $\begin{array}{l}\text { Sea level at } 0.3 \mathrm{~m} \text { b.s.l. Rapid degradation of peat due to peat extraction and anthropogenic drainage ( } 0 \mathrm{~m} \mathrm{~m} \text {.s.l.). } \\
\text { Freshwater lakes develop. Water level River Vecht } 0.05 \mathrm{~m} \text { b.s.l. }\end{array}$ \\
\hline AD 1850-AD 1900 & $\begin{array}{l}\text { Sea level at } 0.1 \mathrm{~m} \text { b.s.l. Reclamation of Haarlemmermeer (AD 1852) and Horstermeer (AD 1882). } \\
\text { Anthropogenic drainage through canals and ditches. }\end{array}$ \\
\hline AD 1900-AD 1950 & Sea level at 0.05 b.s.l. Subsurface drains introduced. Groundwater (over-) abstraction in coastal dunes. \\
\hline AD 1950-AD 2010 & $\begin{array}{l}\text { Present-day situation, sea level at } 0 \mathrm{~m} . \mathrm{s} .1 \text {. Groundwater abstraction in ice-pushed ridge, } \\
\text { groundwater abstraction in coastal dunes decreased. }\end{array}$ \\
\hline
\end{tabular}


Table 3. References for paleo-model implementation.

\begin{tabular}{ll}
\hline Property & References \\
\hline Surface level & Vernes and Van Doorn (2005), Vos (1998), Vos et al. (2011) \\
\hline Sea level rise & $\begin{array}{l}\text { Beets et al. (2003), Denys and Baeteman (1995), Jelgersma (1961), Kiden (1995), Ludwig et al. (1981), } \\
\text { Van de Plassche (1982) }\end{array}$ \\
\hline Geohydrological properties & Van Asselen et al. (2010), Kechavarzi et al. (2010), Stafleu et al. (2013), Vernes and Van Doorn (2005) \\
\hline Recharge & KNMI (2010), Van Loon et al. (2009) \\
\hline Drainage & De Lange et al. (2014), Van Loon et al. (2009) \\
\hline Vecht River system & Bos (2010) \\
\hline Reclaimed areas & Dufour (2000), Schultz (1992) \\
\hline Groundwater abstractions & Van Loon (2010), Oude Essink (1996) \\
\hline
\end{tabular}

important exception is the build-up and subsequent degradation of peat domes; we derived model parameters for peat elevations and extent from a detailed reconstruction located in a similar setting just north of Amsterdam (Vos, 1998). Geohydrological properties for historical surface sediments were assumed to equal their current (buried) properties, except for uncompacted peat deposits, set in accordance to relevant literature values (Kechavarzi et al., 2010).

As no long-term precipitation record exist for the Netherlands, and annual temperatures have remained approximately constant over the past $7 \mathrm{kyr}$ (Davis et al., 2003), we chose to apply a constant uniform recharge of $0.7 \mathrm{~mm} \mathrm{~d}^{-1}$, equal to the current long-term average, for all time slices. We did not differentiate recharge amounts for vegetation types, given the lack of data on past vegetation patterns. North Sea chloride concentration was kept at a constant $16 \mathrm{~g} \mathrm{~L}^{-1}$ over the entire model time, the present average concentration. Initial chloride concentration (at $6500 \mathrm{BC}$ ) was set to $16 \mathrm{~g} \mathrm{~L}^{-1}$ below the area initially inundated by the sea, and zero throughout the remainder of the model, as the $100 \mathrm{kyr}$ period of the Weichselian glacial stage preceding the modeled period is expected to have caused extensive freshening of the Pleistocene aquifers (Post et al., 2003). The only exception is the low permeable Maassluis formation at the bottom of the transect, where limited dated samples indicate only partial freshening of this connate marine groundwater (Post et al., 2003). The initial concentration in the Maassluis formation was therefore assumed to be $10 \mathrm{~g} \mathrm{~L}^{-1}$, the approximate upper limit of measured concentrations (Stuyfzand, 1993). In addition to the described scenario, four additional sensitivity runs were performed to explore two main model uncertainties: dispersivity and the chloride concentration of water present in the Maassluis formation at model start. Dispersivities were decreased 10-fold, and the initial Maassluis concentration was set to 0,5 and $15 \mathrm{~g} \mathrm{~L}^{-1}$ in these runs, respectively, all other parameters remaining unchanged.

\section{Results}

\subsection{Sensitivity runs}

SEAWAT model run time simulating $8.5 \mathrm{kyr}$ and including seven additional mobile species was approximately 3 days on a standard single cpu; no convergence problems were encountered, including at time-slice transitions. The performed sensitivity runs did not reveal a significant influence of dispersivity on the general shape of the present-day salinity distribution. A 10-fold decrease in dispersivity did, however, result in a narrower transition zone between fresh and saline groundwater, most importantly beneath the coastal dunes (100 to $25 \mathrm{~m}$ ). Further inland, the width of the transition zone decreased from around $50 \mathrm{~m}$ to around $25 \mathrm{~m}$. While measurements indicate a narrow transition zone beneath the coastal dunes, they suggest a wide transition zone further inland and are therefore inconclusive in regards to the "better" value. The Maassluis sensitivity runs revealed a clear dependence of the modeled historical trajectory and presentday location of Maassluis water on its initial chloride concentration. While the general processes acting on this water type remain the same, the extent to which Maassluis water is transported through the subsurface is negatively related to its chloride concentration. At $15 \mathrm{~g} \mathrm{~L}^{-1}$, the density difference between infiltrating transgression water and resident Maassluis water clearly provides less incentive for flow than at $0 \mathrm{~g} \mathrm{~L}^{-1}$. As a result, while a significant fraction of Maassluis water is still present at its original location in the $15 \mathrm{~g} \mathrm{~L}^{-1}$ run at model end, it is almost completely displaced in the $0 \mathrm{~g} \mathrm{~L}^{-1}$ run, with the 5 and $10 \mathrm{~g} \mathrm{~L}^{-1}$ scenarios in between those extremes. Comparison with the HYFA results of Stuyfzand (1993), although based on only limited samples at the relevant depths, suggests an initial Maassluis concentration of around $10 \mathrm{~g} \mathrm{~L}^{-1}$, showing agreement in the relatively shallow occurrence of Maassluis at a depth of $100 \mathrm{~m}$ around $x$ coordinate $112 \mathrm{~km}$. 


\subsection{Model validation}

We compared modeled heads with averaged heads measured in 382 piezometers located along the modeled transect (RMSE of 1.4 m, Fig. 4, locations in Fig. 1). Visual inspection revealed a concentration of absolute errors in the coastal dune area: the RMSE of modeled versus measured heads excluding the dune area is a mere $0.7 \mathrm{~m}$. RMSE normalized to the range of observed values (NRMSE) is in both cases $11 \%$. Larger absolute deviations in the coastal dune area were expected given the large head variation over short distances caused by the varied relief, the concentration of well fields and the presence of an artificial recharge installation, factors implemented in the model only in a simplified way. Chloride measurements are available in the study area from AD 1891 onwards, which we compared to concomitant model results (RMSE, NRMSE of $2.7 \mathrm{~g} \mathrm{~L}^{-1}, 16 \%$, respectively, $1.5 \mathrm{~g} \mathrm{~L}^{-1}, 22 \%$ excluding the coastal dunes, locations in Fig. 1). These relatively large RMSEs reflect the difficulty in obtaining good fits between measured and modeled values along a transect due to the large spatial variation in (modeled) chloride concentrations over short distances. Nevertheless, the measured groundwater chloride distribution is approximated quite well (Fig. 5), with the model capturing both the depth of the Badon Ghijben-Herzberg (BGH)-type lens below the coastal dunes and the upward movement of chloride below the inland deep polder areas, even including the occurrence of very localized brackish groundwater below the Horstermeer. Discrepancies around $x$ coordinates 113 and 125 are likely due to the orthogonal projection of chloride measurements on the model transect, and caused by local head gradients not included in the chosen model transect. And while the several tens-of-meters-wide transition zone between fresh and saline water inland is well-captured by the model, the width of the transition zone beneath the BGH lens below the dunes is overestimated by the applied model-wide dispersion parameters. A comparison of available tritium measurements with the modeled 1952 age contour was hampered by the necessary orthogonal projection of the sparsely available tritium measurements on the modeled transect. Notwithstanding, tritium ages generally confirmed the modeled vertical extent of both post-1952 groundwater in infiltration areas around the deep polder Horstermeer, the coastal dunes and the ice-pushed ridge area, and pre-1952 groundwater beneath the exfiltrating deep polder Haarlemmermeer. Age calculation results were omitted from this paper for the sake of brevity, but are included in the film available as supplementary information.

We compared the present-day distribution of modeled origin tracers to results of a hydrochemical facies analysis (HYFA) (Sect. 2.3; Stuyfzand, 1993, 1999) along the model transect, approximately between $x$ coordinates 95 and $110 \mathrm{~km}$ (Fig. 6). HYFA uses the hydrochemistry of groundwater to identify groundwater bodies (hydrosomes) and the hydrochemical zones within them, and thus provides clues

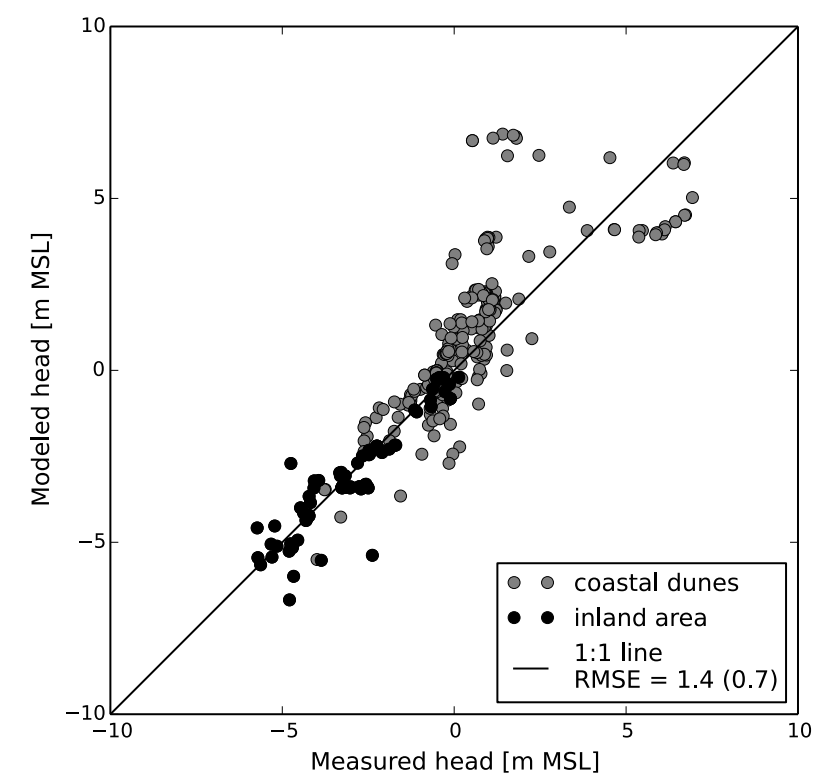

Figure 4. Comparison of measured versus modeled heads. Locations (Fig. 1) were selected within a trapezoidal buffer $(0.5 \mathrm{~km}$ at the surface to $5 \mathrm{~km}$ at $300 \mathrm{~m}$ depth) around and projected orthogonally onto the modeled transect. Measurement values are the average of time series of head measurements from AD 1990 onwards containing at least 25 measurements.

to their respective histories. This comparison therefore provides a comprehensive, independent model test. Various discrepancies exist between the distribution of modeled origin tracers and measured distribution of hydrosomes. Discrepancies are largest at depths greater than $150 \mathrm{~m}$ b.s.l. beneath the coastal dunes, and below $80 \mathrm{~m}$ b.s.l. in the deep polder area. This is due to the depth limits of observation wells (differing in both zones), giving rise to uncertainties in both the hydrochemical, hydraulic and hydrogeological data underlying the HYFA analysis and in the structure of the model. The differences call for further model optimizations where the hydrochemical patterns are very reliable, for instance regarding the advance of the intruding North Sea water, shape of the fresh dune water lens and transition zone below it, and the presence of polder water in the central parts of the deep polder Haarlemmermeer. Overall, however, the comparison shows a clear correspondence between the position of modeled origin tracers and hydrosomes, in both relatively recent (seawater wedge, infiltrating dune water) and older water types (Maassluis water, and water infiltrated during transgression and after extensive peat formation).

\subsection{Evolution of groundwater salinity}

An overview of the modeled evolution of the groundwater chloride distribution is presented in Fig. 7; a film of the evolution of chloride, age and origin tracers is available as supplementary information. Before $4500 \mathrm{BC}$, the coastline 


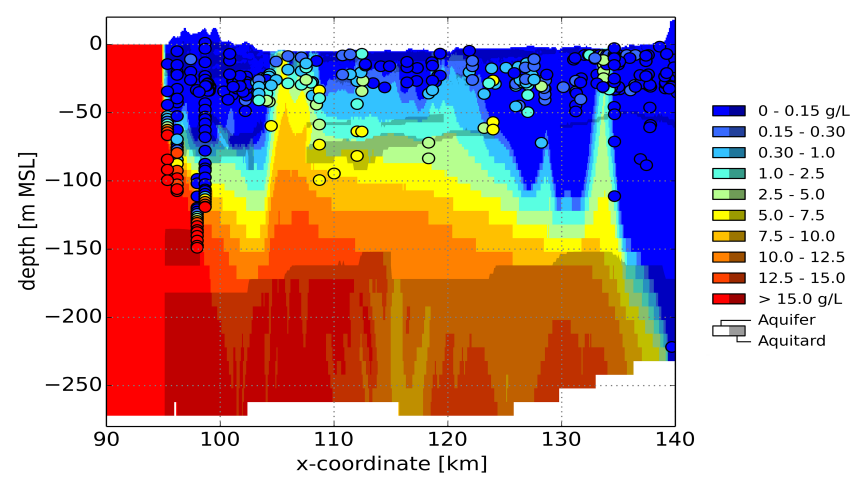

Figure 5. Chloride measurements versus modeled chloride concentration at $\mathrm{AD} 2010$. Measurements were selected within a trapezoidal buffer ( $2 \mathrm{~km}$ (b) at the surface to $5 \mathrm{~km}$ at $300 \mathrm{~m}$ depth) around and projected orthogonally onto the modeled transect.

shifted gradually landward to a maximum of about threequarters of the model transect ( $x$ coordinate $129 \mathrm{~km}$ ), receding to $x$ coordinate $125 \mathrm{~km}$ in $3300 \mathrm{BC}$. Saline water infiltrated below the zone of marine influence through free convection, showing classic fingering patterns (Elder, 1967). Infiltration of marine water was influenced significantly by the presence of aquitards between 50 and $100 \mathrm{~m}$ b.s.l. and below $150 \mathrm{~m}$ b.s.l. Infiltration in the absence of these aquitards (around $x$ coordinate $105 \mathrm{~km}$ ) was rapid, reaching a depth of $150 \mathrm{~m}$ within decades. However, where infiltration water encountered aquitards, the concentration gradient driving free convection and hence infiltration rates decreased. Infiltration water subsequently expanded horizontally (e.g., Fig. 7c, $x$ coordinate $115 \mathrm{~km}$ ), forcing the resident freshwater to flow upwards, resulting in an effective stop to infiltration in this region. Although salinization rates were significantly lower in low-permeable strata, the time available was enough to also completely salinize the aquitards between 50 and $100 \mathrm{~m}$ b.s.l.

Infiltration of transgression water halted completely after the coastal barriers closed around $3300 \mathrm{BC}$ and the inland area freshened. Salinization of deeper layers continued as density differences resulted in a further downward movement and horizontal spreading of the infiltrated water. A BGH-type freshwater lens developed underneath the coastal barriers within centuries and expanded when the elevation of the coastal dunes increased significantly around AD 900. The widespread gradual build-up of peat between $3300 \mathrm{BC}$ and AD 1500 elevated the land between the coastal dunes and the ice-pushed ridge to approximately $3 \mathrm{~m}$ above contemporaneous sea level, resulting in extensive infiltration of meteoric freshwater. Maximum infiltration depth varied between 20 and $100 \mathrm{~m}$ and was reached after about 4 millennia of infiltration. Rates of forced convection of meteoric infiltration water were much lower than those observed for free convection of transgression water, especially where low- permeable strata and underlying saline groundwater impedes downward flow. Infiltration rates were considerably reduced after $\mathrm{AD} 1500$, caused by peat degeneration and the resulting decrease in hydraulic gradients. After the development of the Vecht river system around AD 500 (Fig. 7e, $x$ coordinate $130 \mathrm{~km}$ ), the gaining river Vecht started to attract regional groundwater flow resulting in upconing of the deeper brackish groundwater to about $50 \mathrm{~m}$ b.s.l. Lake reclamations around AD 1850 caused large vertical upward hydraulic gradients, shifting groundwater flow patterns towards the deep polders. The reclamation of the Horstermeer transported the upconed water beneath the Vecht river eastward and further upwards, where it eventually exfiltrated. Effects of the reclamation of the Haarlemmermeer are most pronounced where the aquitards between $50 \mathrm{~m}$ and $100 \mathrm{~m}$ b.s.l. are absent, and brackish groundwater exfiltrates (between $x$ coordinate 103 and $108 \mathrm{~km}$ ). There, groundwater flows upward at a rate of approximately $0.5 \mathrm{~m} \mathrm{yr}^{-1}$, momentarily slowed down between 1900 and 1950 by the overextraction in the dune area. Groundwater below the remaining part of the Haarlemmermeer is still fresh up to a depth of $50 \mathrm{~m}$ b.s.l., owing to the lower upward flow rates due to the presence of aquitards and larger distance to the coastal dunes. The depth and shape of the BGH-type freshwater lens beneath the coastal dunes is not straightforwardly determined by the BGH approximation, but is influenced by both the occurrence of lowpermeable sediments below the dunes and groundwater $a b-$ straction. Moreover, the freshwater lens is displaced eastward as a result of the steep hydraulic gradient towards the Haarlemmermeer.

\subsection{Total salt present}

We calculated the total amount of chloride present in the model (SP), east of the present-day coastline, and the contribution of the different sources of chloride to SP (Fig. 8). SP of transgression origin was the dominant input of chloride $(60 \%)$, Maassluis origin contributed $24 \%$, while seawater intrusion accounted for $17 \%$ of SP. SP predominantly increased before $4500 \mathrm{BC}$, owing to the infiltration of transgraded seawater. As the sea level rose and the coastline progressively moved landward, the passing of discontinuities in these aquitards caused a distinctive accelerating and decelerating pattern in the increase of SP in the model. Infiltration of transgression water reduced after $4500 \mathrm{BC}$, when the continued deposition of marine clays started to pose a considerable resistance to vertical flow. Infiltration of transgression water halted completely after the coastal barriers closed around $3300 \mathrm{BC}$, the continuing increase of SP until $2100 \mathrm{BC}$ is due to a landward migration of coastal barriers. Subsequent infiltration of meteoric water slowly decreased SP until around AD 1500. Extensive drainage, land reclamation and groundwater abstraction resulted in the reversal of groundwater gradients and promoted the landward migration of seawater intrusion, increasing SP in the groundwater 

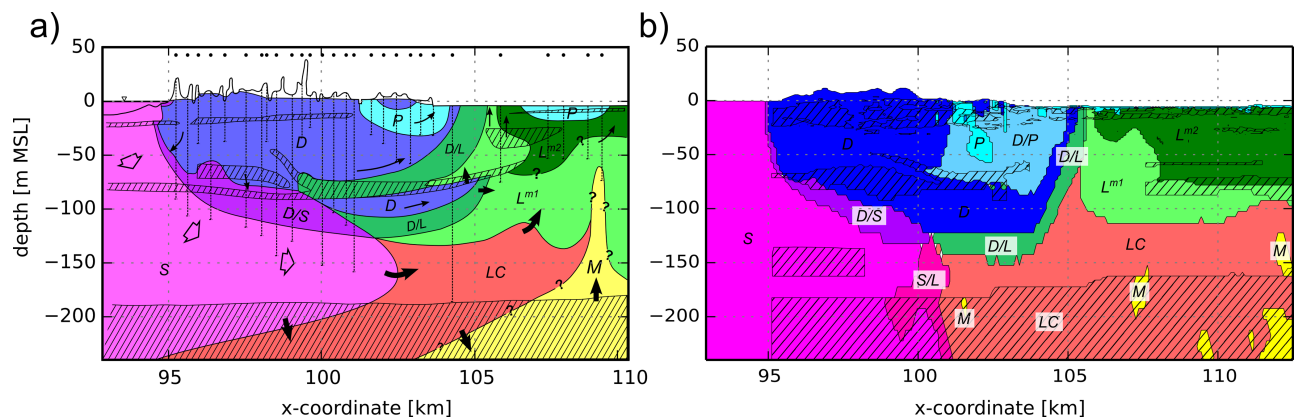

Figure 6. Position of hydrosomes, inferred from hydrochemical facies analysis (adapted from Fig. 4.6 in Stuyfzand, 1993) (a) and from modeled origin tracers (b). Capitals denote discerned hydrosomes: $\mathrm{D}=$ dune (also containing nested artificial recharge hydrosome; not shown), $\mathrm{LC}=$ Holocene transgression $(\mathrm{L})$ - coastal type, $\mathrm{L}^{\mathrm{m} 1}=\mathrm{L}-$ ancient marsh type, $\mathrm{L}^{\mathrm{m} 2}=\mathrm{L}-$ young marsh type, $\mathrm{M}=\mathrm{Maassluis}$, $\mathrm{P}=$ polder, $\mathrm{S}=$ (actual) North Sea. See Sect. 2.3 for a description of discerned hydrosomes, and Table 1 for the mapping of origin tracers to hydrosomes, dots and dashed lines in (a) denote locations of piezometers used in HYFA.
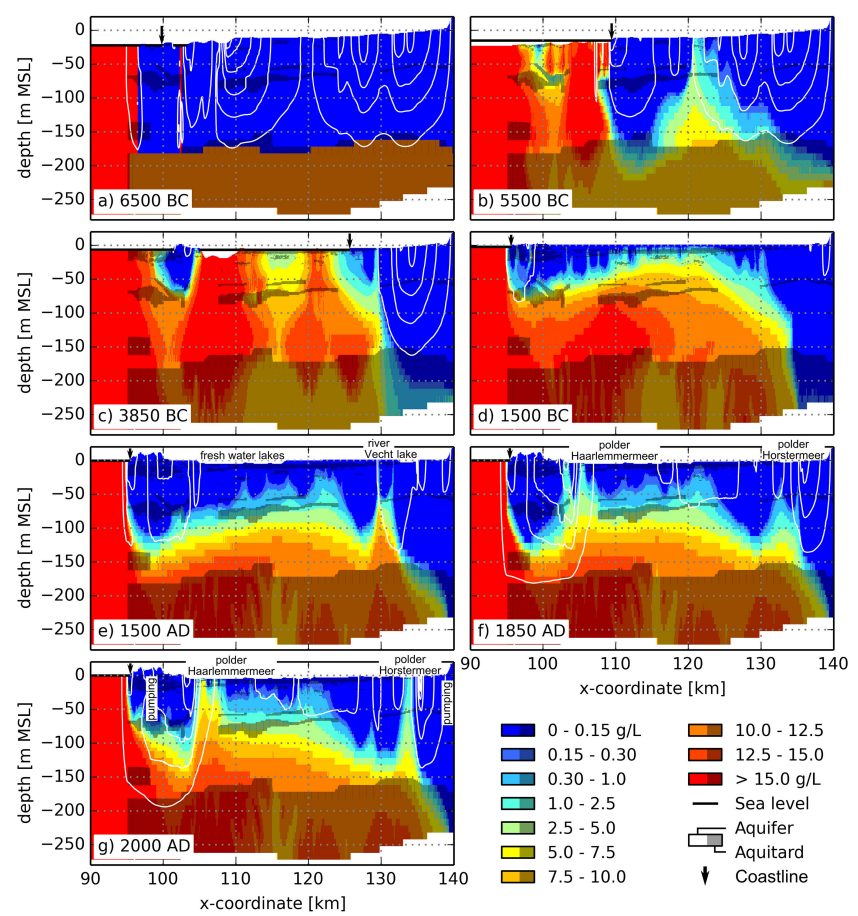

Figure 7. Modeled evolution of groundwater chloride concentration (a-g). White lines are contours of the stream function, contour intervals are equal for all time slices. Except for (a) (starting concentration), transect times correspond to paleo-geographical maps in Fig. 2.

system. The steep increase in SP of sea origin between 1900 and 1950 was caused by groundwater (over-) abstraction in the coastal dunes.

\subsection{Origin tracers}

The modeled origin tracers provided a comprehensive overview of the evolution of groundwater types of differ-

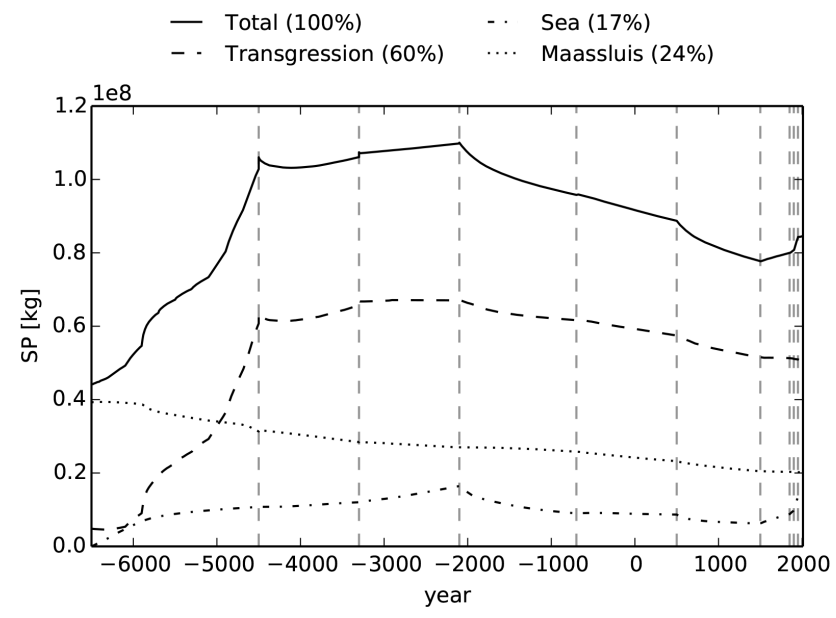

Figure 8. Contribution of transgression, sea, and Maassluis to total salt present (SP). Only the model domain east from $x$ coordinate $95 \mathrm{~km}$ is considered. Vertical dashed lines denote time-slice transitions, discontinuities at transitions result from changing numbers of active model cells. Legend percentages are percentages at model end.

ent origin (Fig. 9). As already noted, widespread infiltration of transgression water occurred through free convection between 6500 and $3300 \mathrm{BC}$. The infiltration had a pronounced effect on other tracers, as resident older water was pushed upwards around the infiltrating fingers. This mechanism is most readily apparent in the evolution of Maassluis water, mobilized from its original position below $170 \mathrm{~m}$ b.s.l. upwards to the ground surface (Fig. 9b). After marine infiltration stopped, the mobilized Maassluis water moved gradually downward, while the Maassluis water still present at greater depths was slowly displaced upwards by the more saline transgression water due to density differences. This combination resulted in its fairly compact present position below around $80 \mathrm{mb}$.s.l. and east of $x$ coordinate $115 \mathrm{~km}$. The upward movement of groundwater after the reclamation 


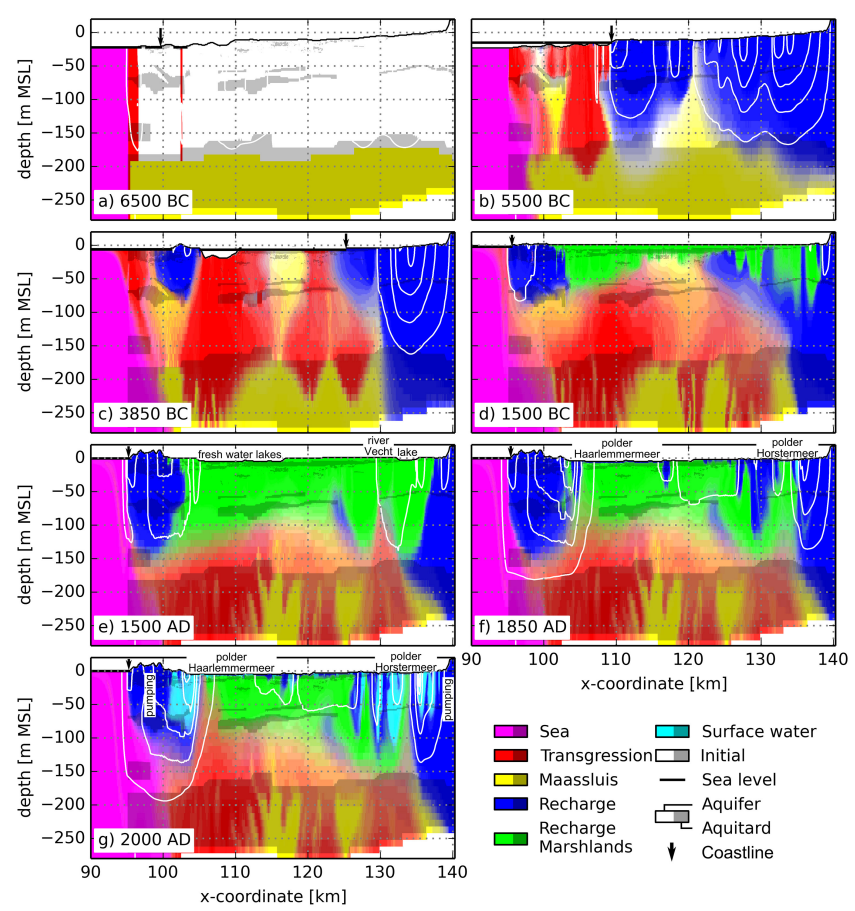

Figure 9. Modeled evolution of groundwater origin (a-g). White lines are contours of the stream function, contour intervals are equal for all time slices. Except for (a) (starting situation), transect times correspond to paleo-geographical maps in Fig. 2.

of polder Haarlemmermeer, put forward by Stuyfzand (1993) to explain the present-day position of Maassluis water, was shown to be only of minor influence.

The infiltration of meteoric infiltration water caused the submarine groundwater discharge of earlier transgression water seaward of the coastal dunes (Fig. 9d, $x$ coordinate $95 \mathrm{~km}$ ), owing to a regional seaward flow system underlying the coastal dunes. The influence of the classic seawater intrusion mechanism, the landward-intruding seawater wedge (origin tracer sea), was limited to about $5 \mathrm{~km}$ from the coastline, in general agreement with results of Stuyfzand (1993). Maassluis water constituted the third input of chloride, mainly contributing to chloride concentrations in the eastern part of the model transect.

\section{Discussion}

While the paleo-geographical development of the Netherlands is relatively well documented, based on numerous investigations of the near-surface geology, carbon dating and archeological evidence (Vos and Gerrets, 2005; Vos et al., 2011; Weerts et al., 2005), such reconstructions necessarily entail a significant degree of interpretation and hence uncertainty. This uncertainty is only enlarged in a paleohydrogeological model, both through model simplification and the introduction of additional uncertain parameters (e.g., climate, sea salinity, historical surface elevation, and hydraulic parameters of the subsurface). In addition, the employed 2-D approach neglects variation perpendicular to the model transect, and the use of time slices introduces discrete and significant jumps in the gradually changing geology and hydrology. Finally, the chosen model discretization prevents the inclusion of boils, highly localized conduits penetrating the low-permeable Holocene strata (De Louw et al., 2010) that contribute significantly to the exfiltration of salts in the polder Haarlemmermeer (Delsman et al., 2013). We did not attempt to quantify the uncertainty in our model, and therefore do not claim its validity other than as a conceptual tool. Nevertheless, judging from comparisons to measured heads, chloride concentrations, age patterns and, perhaps most assuring, hydrochemical facies analysis, the model appears to explain the present-day distribution of both groundwater salinity and origin quite well. We are confident, therefore, that the important processes occurring over the modeled period, responsible for the present-day salinity distribution on the scale considered, are well represented by the paleohydrogeological model.

The influence of variable density on groundwater flow patterns has been widely demonstrated in either idealized smallscale numerical or sandbox experiments (e.g., Simmons et al., 2001; Post and Kooi, 2003; Post and Simmons, 2009; Jakovovic et al., 2011) or in numerical studies describing present-day salinization patterns in real-world aquifers (e.g., Oude Essink et al., 2010; Nocchi and Salleolini, 2013; Cobaner et al., 2012). However, reports on the long-term effects of these processes in real-world aquifers over the timescales considered here have remained scarce. Post and Kooi (2003) investigated the ability of free convective infiltration to salinize high-permeable aquifers, and reported possible infiltration velocities of several meters per year. With infiltrating saltwater reaching $150 \mathrm{~m}$ depth within decades where aquitards are absent, our results confirm these findings. In addition, they show the importance of these "infiltration hotspots" for the salinization of regions underlying lowpermeable strata (Simmons et al., 2001). Our results further signify that aquitards at greater depths can effectively impede infiltration in overlying strata, with effects still visible in the present-day salinity distribution. However, we did not find aquitards that effectively resist salinization or freshening (Groen et al., 2000): the timescales considered are evidently long enough, and hydraulic gradients high enough in the considered setting to eventually lead to salinization or freshening. Mixing zones between salt- and freshwater have been reported to vary widely in geologic settings across the world (Werner et al., 2013), resulting from diffusive processes and kinetic mass transfer (Lu et al., 2009). Measurements indicate that mixing zones even vary widely within our modeled transect, from a narrow zone of some meters around the BGH lens beneath the coastal dunes, to a wide vertical mixing zone of several tens of meters inland. We attribute this variation to the difference between the relatively steady 
evolution of the BGH lens, resulting in a transition width controlled by molecular diffusion and pore-scale transversal dispersion (Paster and Dagan, 2007), versus the highly transient evolution history of groundwater salinity on the landward side. Wide mixing zones associated with vertical seawater intrusion result from the slow mixing of small-scale (meters) seawater fingers with the intermediary freshwater after the fingers reach the aquifer bottom and flow effectively stops (Kooi et al., 2000). Model-wide dispersivity values could not satisfactorily simulate both these extremes. A dual-domain approach (Lu et al., 2009) could perhaps yield better results.

The present-day salinity distribution in the coastal zone of the Netherlands has been widely recognized to result from free-convective infiltration during Holocene transgressions, widespread peat development and subsequent degradation, and the increasing anthropogenic influence in the more recent past (Post, 2004; Stuyfzand, 1993). Our modeling results clearly support this evolution history, but provide a more detailed overview of the processes involved, signifying the role of aquitards, the ice-pushed ridge flow system, and premodel Maassluis water. The role of (connate) salt present in the Maassluis formation in explaining the present-day salinity distribution has been the subject of some controversy over the past decades, with some authors attributing the presence of brackish groundwater in Pleistocene aquifers to upwards diffusion of salts from this formation (Meinardi, 1991; Volker, 1961). Our results indicate that (1) some salt must have been initially (i.e., at model start, $6500 \mathrm{BC}$ ) present in this formation to explain the present-day occurrence of this water type, (2) this salt was rapidly mobilized during the marine transgression in the Holocene, and (3) pre-model salt still contributes with a significant percentage to the presentday salinity distribution. The evolution of salinity in the Maassluis formation throughout the trans- and regression periods during the Quaternary clearly deserves further study.

Regional-scale numerical modeling studies to understand present-day or predict future variable density flow in realworld aquifers are faced with the problem of applying an initial salinity distribution, inherently unknown as measurements are sparse and salinity varies on short-length scales. An often-applied approach is the assumption of steady state, conditioned on present-day boundary conditions (e.g., Souza and Voss, 1987; Vandenbohede and Lebbe, 2002). Such an approach is clearly not warranted for coastal aquifers as the one considered here, as the present-day salinity distribution is almost entirely determined by the significant paleogeographical changes occurring throughout the Holocene. Moreover, neither the salinity distribution nor, consequently, the head distribution was, throughout the modeled period, ever in steady state. A second approach is the construction of the initial salinity distribution based on available measurements, generally by three-dimensional interpolation of available point measurements of salinity (Van der Meij and Minnema, 1999; Oude Essink et al., 2010). This approach necessarily disregards the many small-scale salinity variations not represented by measurements, resulting in an initial salinity distribution not in equilibrium with applied boundary conditions and, consequently, in difficult-to-detect model artifacts. Recent advances have been made in the application of airborne geophysical techniques (AEM) to map groundwater salinity variations over larger scales as input to numerical models (Faneca Sànchez et al., 2012). While this technique is very promising, adequate separation of the contribution of lithology and salinity in the acquired signal requires elaborate ground-truthing (Gunnink et al., 2012), but the resolution of AEM is too coarse to delineate small-scale features and its accuracy decreases with depth. The primarily conceptual paleo-geographical modeling approach presented in this paper cannot yet claim to provide an alternative to the above approaches. Ultimately however, the incorporation of the presented approach within a rigorous uncertainty framework, calibrated to an increasing amount of present-day salinity data supplemented with airborne techniques, may prove successful in adequately describing present-day salinity distributions.

\section{Conclusions}

We successfully modeled the effect of paleo-geographical changes throughout the Holocene on the intrusion and redistribution of salts in a representative coastal aquifer. This approach refined our current understanding of the evolution of the salinity distribution in the coastal region of the Netherlands, and yielded insights into the long-term, real-world effects of processes previously investigated in idealized experimental settings. Not once reaching steady state throughout the Holocene, our results attest to the long-term dynamics of salinity in coastal aquifers. The implications of our results extend beyond understanding the present-day distribution of salinity, as the proven complex history of coastal groundwater holds important clues for understanding the distribution of other societally relevant groundwater constituents like nutrients (Van Rees Vellinga et al., 1981; Stuyfzand, 1993) and arsenic (Harvey et al., 2006; Michael and Voss, 2009).

\section{The Supplement related to this article is available online at doi:10.5194/hess-18-3891-2014-supplement.}

Acknowledgements. We thank Jeroen Schokker for providing GeoTop data, and Kim Cohen and Wim de Lange for the valuable discussions on paleo-geography and groundwater flow. We thank two anonymous reviewers whose constructive comments helped improve this paper. This work was carried out within the Dutch Knowledge for Climate program.

Edited by: S. Attinger 


\section{References}

Barlow, P. M. and Reichard, E. G.: Saltwater intrusion in coastal regions of North America, Hydrogeol. J., 18, 247-260, doi:10.1007/s10040-009-0514-3, 2009.

Beets, D. J., De Groot, T. A. M., and Davies, H. A.: Holocene tidal back-barrier development at decelerating sea-level rise: a 5 millennia record, exposed in the western Netherlands, Sediment. Geol., 158, 117-144, doi:10.1016/S0037-0738(02)002634, 2003.

Bense, V. F. and Person, M. A.: Transient hydrodynamics within intercratonic sedimentary basins during glacial cycles, J. Geophys. Res., 113, F04005, doi:10.1029/2007JF000969, 2008.

Bos, I. J.: Distal delta-plain successions: architecture and lithofacies of organics and lake fills in the Holocene Rhine-Meuse delta, The Netherlands, PhD thesis, Faculty of Geosciences, Utrecht University, 208 pp., 2010.

Cobaner, M., Yurtal, R., Dogan, A., and Motz, L. H.: Three dimensional simulation of seawater intrusion in coastal aquifers: A case study in the Goksu Deltaic Plain, J. Hydrol., 464-465, 262-280, doi:10.1016/j.jhydrol.2012.07.022, 2012.

Custodio, E.: Aquifer overexploitation: what does it mean?, Hydrogeol. J., 10, 254-277, doi:10.1007/s10040-002-0188-6, 2002.

Custodio, E. and Bruggeman, G. A.: Groundwater problems in coastal areas, Studies an, UNESCO, Paris, 1987.

Davis, B. A. S., Brewer, S., Stevenson, A. C. and Guiot, J.: The temperature of Europe during the Holocene reconstructed from pollen data, Quaternary Sci. Rev., 22, 1701-1716, doi:10.1016/S0277-3791(03)00173-2, 2003.

De Lange, W. J., Prinsen, G. F., Hoogewoud, J. C., Veldhuizen, A. A., Verkaik, J., Oude, G. H. P., Walsum, P. E. V. Van, Delsman, J. R., Hunink, J. C., Massop, H. T. L., and Kroon, T.: An operational, multi-scale, multi-model system for consensus-based, integrated water management and policy analysis: The Netherlands Hydrological Instrument, Environ. Model. Softw., 59, 98 108, doi:10.1016/j.envsoft.2014.05.009, 2014.

De Louw, P. G. B., Oude Essink, G. H. P., Stuyfzand, P. J., and Van der Zee, S. E. A. T. M.: Upward groundwater flow in boils as the dominant mechanism of salinization in deep polders, The Netherlands, J. Hydrol., 394, 494-506, doi:10.1016/j.jhydrol.2010.10.009, 2010.

De Louw, P. G. B., Eeman, S., Siemon, B., Voortman, B. R., Gunnink, J., van Baaren, E. S., and Oude Essink, G. H. P.: Shallow rainwater lenses in deltaic areas with saline seepage, Hydrol. Earth Syst. Sci., 15, 3659-3678, doi:10.5194/hess-15-36592011, 2011.

Delsman, J. R., Oude Essink, G. H. P., Beven, K. J., and Stuyfzand, P. J.: Uncertainty estimation of end-member mixing using generalized likelihood uncertainty estimation (GLUE), applied in a lowland catchment, Water Resour. Res., 49, 4792-4806, doi:10.1002/wrcr.20341, 2013.

Denys, L. and Baeteman, C.: Holocene evolution of relative sea level and local mean high water spring tides in Belgium a first assessment, Mar. Geol., 124, 1-19, doi:10.1016/00253227(95)00029-X, 1995.

Dufour, F. C.: Groundwater in the Netherlands: Facts and figures, Netherlands Inst. of Applied Geoscience TNO, 2000.

Elder, J.: Transient convection in a porous medium, J. Fluid Mech., 27, 609-623, 1967.
Faneca Sànchez, M., Gunnink, J. L., Van Baaren, E. S., Oude Essink, G. H. P., Siemon, B., Auken, E., Elderhorst, W., and De Louw, P. G. B.: Modelling climate change effects on a Dutch coastal groundwater system using airborne electromagnetic measurements, Hydrol. Earth Syst. Sci., 16, 4499-4516, doi:10.5194/hess-16-4499-2012, 2012.

Ferguson, G. and Gleeson, T.: Vulnerability of coastal aquifers to groundwater use and climate change, Nat. Clim. Chang., 2, 342345, doi:10.1038/nclimate1413, 2012.

Gelhar, L. W., Welty, C., and Rehfeldt, K. R.: A critical review of data on field-scale dispersion in aquifers, Water Resour. Res., 28, 1955-1974, 1992.

Goode, D. J.: Direct simulation of groundwater age, Water Resour. Res., 32, 289-296, 1996.

Groen, J., Velstra, J., and Meesters, A. G. C. A.: Salinization processes in paleowaters in coastal sediments of Suriname: evidence from $837 \mathrm{Cl}$ analysis and diffusion modelling, J. Hydrol., 234, 120, doi:10.1016/S0022-1694(00)00235-3, 2000.

Gunnink, J. L., Bosch, J. H. A., Siemon, B., Roth, B., and Auken, E.: Combining ground-based and airborne EM through Artificial Neural Networks for modelling glacial till under saline groundwater conditions, Hydrol. Earth Syst. Sci., 16, 30613074, doi:10.5194/hess-16-3061-2012, 2012.

Harvey, C. F., Ashfaque, K. N., Yu, W., Badruzzaman, A. B. M., Ali, M. A., Oates, P. M., Michael, H. A., Neumann, R. B., Beckie, R., Islam, S., and Ahmed, M. F.: Groundwater dynamics and arsenic contamination in Bangladesh, Chem. Geol., 228, 112-136, doi:10.1016/j.chemgeo.2005.11.025, 2006.

Jakovovic, D., Werner, A. D., and Simmons, C. T.: Numerical modelling of saltwater up-coning: Comparison with experimental laboratory observations, J. Hydrol., 402, 261-273, doi:10.1016/j.jhydrol.2011.03.021, 2011.

Jelgersma, S.: Holocene sea level changes in the Netherlands, $\mathrm{PhD}$ thesis, Leiden University, 100 pp., 1961.

Jelgersma, S., De Jong, J., and Zagwijn, W. H.: The Coastal Dunes of the Western Netherlands: Geology, Vegetational History and Archaeology, Ernest van Aelst, Maastricht, the Netherlands, 1970.

Kechavarzi, C., Dawson, Q., and Leeds-Harrison, P. B.: Physical properties of low-lying agricultural peat soils in England, Geoderma, 154, 196-202, doi:10.1016/j.geoderma.2009.08.018, 2010.

Kiden, P.: Holocene relative sea-level change and crustal movement in the southwestern Netherlands, Mar. Geol., 124, 21-41, doi:10.1016/0025-3227(95)00030-3, 1995.

KNMI: Schiphol, langjarige gemiddelden, tijdvak 1981-2010, De Bilt, 2010.

Konikow, L. F.: The Secret to Successful Solute-Transport Modeling, Ground Water, 1-16, doi:10.1111/j.17456584.2010.00764.x, 2010.

Kooi, H., Groen, K., and Leijnse, A.: Modes of seawater intrusion during transgressions, Water Resour. Res., 36, 3581-3589, doi:10.1029/2000WR900243, 2000.

Kundzewicz, Z., Mata, L., Arnell, N., Döll, P., Jimenez, B., Miller, K., Oki, T., Sen, Z., and Shiklomanov, I.: The implications of projected climate change for freshwater resources and their management, Hydrol. Sci. J., 53, 37-41, 2008.

Langevin, C. D. and Guo, W.: MODFLOW/MT3DMS-based simulation of variable-density ground water flow and 
transport., Ground Water, 44, 339-351, doi:10.1111/j.17456584.2005.00156.x, 2006.

Lebbe, L.: Parameter identification in fresh-saltwater flow based on borehole resistivities and freshwater head data, Adv. Water Resour., 22, 791-806, 1999.

Lebbe, L., Adams, R., and De Deckere, E.: Modeling of historical evolution of salt water distribution on the right bank of the Scheldt in the Antwerp harbor, in: Proc. 22nd Salt Water Intrusion Meeting., 2012.

Lemieux, J.-M. and Sudicky, E. A.: Simulation of groundwater age evolution during the Wisconsinian glaciation over the Canadian landscape, Environ. Fluid Mech., 10, 91-102, doi:10.1007/s10652-009-9142-7, 2009.

Lu, C., Kitanidis, P. K., and Luo, J.: Effects of kinetic mass transfer and transient flow conditions on widening mixing zones in coastal aquifers, Water Resour. Res., 45, W12402, doi:10.1029/2008WR007643, 2009.

Ludwig, G., Müller, H., and Streif, H.: New Dates on Holocene SeaLevel Changes in the German Bight, in: Holocene Marine Sedimentation in the North Sea Basin, edited by: Nio, S. D., Shüttenhelm, R. T. E., and Van Weering, T. C. E., 211-219, Wiley Online Library, 1981.

Makkink, G. F.: Testing the Penman formula by means of lysimeters, J. Inst. Water Eng., 11, 277-288, 1957.

Meinardi, C.: The origin of brackish groundwater in the lower parts of the Netherlands, in: Hydrogeology of salt water intrusion: A selection of SWIM papers Internation Contributions to Hydrogeology, edited by: De Breuck, W., 271-290, Hannover, Germany, 1991

Michael, H. A. and Voss, C. I.: Controls on groundwater flow in the Bengal Basin of India and Bangladesh: regional modeling analysis, Hydrogeol. J., 17, 1561-1577, doi:10.1007/s10040-0080429-4, 2009.

Mulholland, P., Best, G., Coutant, C., Hornberger, G., Meyer, J., Robinson, P., Stenberg, J., Turner, R., Vera-Herrera, F., and Wetzel, R.: Effects of climate change on freshwater ecosystems of the south-eastern United States and the Gulf Coast of Mexico, Hydrol. Process., 11, 949-970, 1997.

Nienhuis, P., Kamps, P., and Olsthoorn, T. N.: 160 Years of History of the Amsterdam Water Supply Dune Area Modeled with Variable Density, Outlook into the Future, in: Proc. of MODFLOW and More 2013: Translating Science into Practice, edited by: Maxwell, R., Hill, M., Zheng, C., and Tonkin, M., Golden, CO, USA, 2013.

Nocchi, M. and Salleolini, M.: A 3D density-dependent model for assessment and optimization of water management policy in a coastal carbonate aquifer exploited for water supply and fish farming, J. Hydrol., 492, 200-218, doi:10.1016/j.jhydrol.2013.03.048, 2013.

Oude Essink, G. H. P.: Impact of sea level rise on groundwater flow regimes: A sensitivity analysis for the Netherlands, $\mathrm{PhD}$ thesis, Faculty of Civil Engineering and Geosciences, Delft University of Technology, 411 pp., 1996.

Oude Essink, G. H. P., Van Baaren, E. S., and De Louw, P. G. B.: Effects of climate change on coastal groundwater systems: A modeling study in the Netherlands, Water Resour. Res., 46, 116, doi:10.1029/2009WR008719, 2010.
Paster, A. and Dagan, G.: Mixing at the interface between two fluids in porous media: a boundary-layer solution, J. Fluid Mech., 584, 455-472, doi:10.1017/S0022112007006532, 2007.

Person, M. A., Bense, V. F., Cohen, D., and Banerjee, A.: Models of ice-sheet hydrogeologic interactions: a review, Geofluids, 12, 58-78, doi:10.1111/j.1468-8123.2011.00360.x, 2012.

Piotrowski, J.: Subglacial hydrology in north-western Germany during the last glaciation: groundwater flow, tunnel valleys and hydrological cycles, Quaternary Sci. Rev., 16, 169-185, 1997.

Pitman, M. and Läuchli, A.: Global impact of salinity and agricultural ecosystems, in: Salinity: environment-plants-molecules, edited by: Läuchli, A. and Lüttge, U., 3-20, Kluwer Academic Publishers, Dordrecht, 2002.

Post, V. E. A.: Groundwater salinization processes in the coastal area of the Netherlands due to transgressions during the Holocene, PhD thesis, Faculty of Earth Sciences, VU University Amsterdam, 154 pp., 2004.

Post, V. E. A. and Abarca, E.: Preface: Saltwater and freshwater interactions in coastal aquifers, Hydrogeol. J., 18, 1-4, doi:10.1007/s10040-009-0561-9, 2009.

Post, V. E. A. and Kooi, H.: Rates of salinization by free convection in high-permeability sediments: insights from numerical modeling and application to the Dutch coastal area, Hydrogeol. J., 11, 549-559, doi:10.1007/s10040-003-0271-7, 2003.

Post, V. E. A. and Simmons, C. T.: Free convective controls on sequestration of salts into low-permeability strata: insights from sand tank laboratory experiments and numerical modelling, Hydrogeol. J., 18, 39-54, doi:10.1007/s10040-009-0521-4, 2009.

Post, V. E. A., Plicht, H., and Meijer, H.: The origin of brackish and saline groundwater in the coastal area of the Netherlands, Netherlands J. Geosci./Geol. en Mijnb., 82, 133-147, 2003.

Ranjan, P., Kazama, S., and Sawamoto, M.: Effects of climate change on coastal fresh groundwater resources, Global Environ. Chang., 16, 388-399, doi:10.1016/j.gloenvcha.2006.03.006, 2006.

Sanford, W. E. and Buapeng, S.: Assessment of a groundwater flow model of the Bangkok Basin, Thailand, using carbon-14-based ages and paleohydrology, Hydrogeol. J., 4, 26-40, 1996.

Schot, P. P. and Molenaar, A.: Regional changes in groundwater flow patterns and effects on groundwater composition, J. Hydrol., 130, 151-170, doi:10.1016/0022-1694(92)90108-8, 1992.

Schultz, B.: De waterbeheersing van droogmakerijen, $\mathrm{PhD}$ thesis, Faculty of Civil Engineering and Geosciences, Delft University of Technology, 506 pp., 1992.

Siemon, B., Christiansen, A. V., and Auken, E.: A review of helicopter-borne electromagnetic methods for groundwater exploration, Near Surf. Geophys., 7, 629-646, 2009.

Simmons, C. T., Fenstemaker, T. R., and Sharp, J. M.: Variabledensity groundwater flow and solute transport in heterogeneous porous media: approaches, resolutions and future challenges., J. Contam. Hydrol., 52, 245-275, 2001.

Souza, W. R. and Voss, C. I.: Analysis of an anisotropic coastal aquifer system using variable-density flow and solute transport simulation, J. Hydrol., 23, 17-41, 1987.

Stafleu, J., Maljers, D., and Gunnink, J. L.: 3D modelling of the shallow subsurface of Zeeland, the Netherlands, Netherlands J. Geosci./Geol. en Mijnb., 90, 293-310, 2011.

Stafleu, J., Maljers, D., Busschers, F. S., Gunnink, J. L. J. L., Schokker, J., Dambrink, R. M., Hummelman, H. J., and Schijf, 
M. L.: GeoTop modellering, TNO report R10991, Netherlands Inst. of Applied Geoscience TNO, Utrecht, 2013.

Stuyfzand, P. J.: Hydrochemistry and hydrology of the coastal dune area of the Western Netherlands, PhD thesis, Faculty of Earth Sciences, VU University Amsterdam, 362 pp., 1993.

Stuyfzand, P. J.: Salinization of drinking water in the Netherlands: anamnesis, diagnosis and remediation, in: Proceedings of the 14th Saltwater Intrusion Meeting, Malmö, Sweden, 168-177, Malmö, Sweden., 1996.

Stuyfzand, P. J.: Patterns in groundwater chemistry resulting from groundwater flow, Hydrogeol. J., 7, 15-27, doi:10.1007/s100400050177, 1999.

Sulzbacher, H., Wiederhold, H., Siemon, B., Grinat, M., Igel, J., Burschil, T., Günther, T., and Hinsby, K.: Numerical modelling of climate change impacts on freshwater lenses on the North Sea Island of Borkum using hydrological and geophysical methods, Hydrol. Earth Syst. Sci., 16, 3621-3643, doi:10.5194/hess-163621-2012, 2012.

Van Asselen, S., Stouthamer, E., and Smith, N. D.: Factors controlling peat compaction in alluvial floodplains: a case study in the cold-temperate Cumberland Marshes, Canada, J. Sediment. Res., 80, 155-166, 2010.

Vandenbohede, A. and Lebbe, L.: Numerical modelling and hydrochemical characterisation of a fresh-water lens in the Belgian coastal plain, Hydrogeol. J., 10, 576-586, doi:10.1007/s10040002-0209-5, 2002.

Vandenbohede, A., Hinsby, K., Courtens, C., and Lebbe, L.: Flow and transport model of a polder area in the Belgian coastal plain: example of data integration, Hydrogeol. J., 19, 1599-1615, doi:10.1007/s10040-011-0781-7, 2011.

Van de Plassche, O.: Sea-level change and water-level movements in the Netherlands during the Holocene, PhD thesis, Faculty of Earth Sciences, VU University Amsterdam, 1982.

Van der Meij, J. and Minnema, B.: Modelling of the effect of a sealevel rise and land subsidence on the evolution of the groundwater density in the subsoil of the northern part of the Netherlands, J. Hydrol., 226, 152-166, doi:10.1016/S0022-1694(99)00150-X, 1999.

Van der Meulen, M., Doornenbal, J., Gunnink, J. L., Stafleu, J., Schokker, J., Vernes, R. W., Van Geer, F. C., Van Gessel, S. F., Van Heteren, S., Van Leeuwen, R. J. W., Bakker, M. A. J., Bogaard, P. J. F., Busschers, F. S., Griffioen, J., Gruijters, S. H. L. L., Kiden, P., Schroot, B. M., Simmelink, H. J., Van Berkel, W. O., Van der Krogt, R. A. A., Westerhoff, W. E., and Van Daalen, T. M.: 3D geology in a 2D country: perspectives for geological surveying in the Netherlands, Netherlands J. Geosci./Geol. en Mijnb., 92, 217-241, 2013.

Vandevelde, D., Kaland, L., Lermytte, J., Lebbe, L., Oude Essink, G. H. P., Vandenbohede, A., Janssen, G., Claus, J., D'Hont, D., and Thomas, P.: Modelling the historical evolution of the freshsalt water distribution in a Dutch-Flemish transboundary aquifer, in: Proc. 22nd Salt Water Intrusion Meeting, 2012.

Van Loon, A. H.: Unravelling hydrological mechanisms behind fen deterioration in order to design restoration strategies, $\mathrm{PhD}$ thesis, Faculty of Geosciences, Utrecht University, 140 pp., 2010.
Van Loon, A. H., Schot, P. P., Griffioen, J., Bierkens, M. F. P., and Wassen, M. J. J.: Palaeo-hydrological reconstruction of a managed fen area in The Netherlands, J. Hydrol., 378, 205-217, doi:10.1016/j.jhydrol.2009.09.014, 2009.

Van Rees Vellinga, E., Toussaint, C., and Wit, K.: Water quality and hydrology in a coastal region of the Netherlands, J. Hydrol., 50, 105-127, 1981.

Vernes, R. W. and Van Doorn, T. H. M.: Van Gidslaag naar Hydrogeologische Eenheid - Toelichting op de totstandkoming van de dataset REGIS II, TNO report, Netherlands Inst. of Applied Geoscience TNO, Utrecht, the Netherlands, 2005.

Volker, A.: Source of brackish ground water in Pleistocene formations beneath the Dutch polderland, Econ. Geol., 56, 1045-1057, 1961.

Vos, P. C.: Profiel reconstructies door de Zaanstreek tussen Groenedijk en Twiske (3000 v. Chr.-heden), Aanvullende geologische informatie [Profile reconstructions in the Zaan area between Groenedijk and Twiske (3000 BC-present), Supplemental geological information], TNO report, Netherlands Inst. of Applied Geoscience TNO, Delft, 1998.

Vos, P. C. and Gerrets, D. A.: Archaeology: a major tool in the reconstruction of the coastal evolution of Westergo (northern Netherlands), Quaternary Int., 133-134, 61-75, doi:10.1016/j.quaint.2004.10.008, 2005.

Vos, P. C., Bazelmans, J., Weerts, H. J. T., and der Meulen, M.: Atlas van Nederland in het Holoceen [Atlas of the Netherlands during the Holocene], Bert Bakker, Amsterdam, 2011.

Weerts, H. J. T., Westerhoff, W. E., Cleveringa, P., Bierkens, M. F. P., Veldkamp, J. G., and Rijsdijk, K. F.: Quaternary geological mapping of the lowlands of The Netherlands, a 21st century perspective, Quaternary Int., 133-134, 159-178, doi:10.1016/j.quaint.2004.10.011, 2005.

Werner, A., Bakker, M., Post, V. E. A., Vandenbohede, A., Lu, C., Ataie-Ashtiani, B., Simmons, C. T., and Barry, D. A.: Seawater intrusion processes, investigation and management: Recent advances and future challenges, Adv. Water Resour., 51, 3-26, doi:10.1016/j.advwatres.2012.03.004, 2013.

Zheng, C.: Recent Developments and Future Directions for MT3DMS and Related Transport Codes, Ground Water, 47, 620 625, doi:10.1111/j.1745-6584.2009.00602.x, 2009.

Zheng, C. and Wang, P.: MT3DMS: A Modular Three-Dimensional Multispecies Transport Model for Simulation of Advection, Dispersion, and Chemical Reactions of Contaminants in Groundwater Systems; Documentation and User's Guide, Washington, DC, 1999.

Zwertvaegher, A., Finke, P., De Reu, J., Vandenbohede, A., Lebbe, L., Bats, M., De Clercq, W., De Smedt, P., Gelorini, V., Sergant, J., Antrop, M., Bourgeois, J., De Maeyer, P., Van Meirvenne, M., Verniers, J., and Crombé, P.: Reconstructing Phreatic Palaeogroundwater Levels in a Geoarchaeological Context: A Case Study in Flanders, Belgium, Geoarchaeology, 28, 170-189, doi:10.1002/gea.21435, 2013. 